\title{
The Performance of Sharia Financing Amid the COVID-19 Pandemic in Indonesia
}

\author{
Muthoifin \\ Department of Islamic Law and Economy, Universitas Muhammadiyah Surakarta, Indonesia
}

Received June 3, 2021; Revised June 29, 2021; Accepted August 22, 2021

\section{Cite This Paper in the following Citation Styles}

(a): [1] Muthoifin , "The Performance of Sharia Financing Amid the COVID-19 Pandemic in Indonesia," Universal Journal of Accounting and Finance, Vol. 9, No. 4, pp. 757 - 763, 2021. DOI: 10.13189/ujaf.2021.090421.

(b): Muthoifin (2021). The Performance of Sharia Financing Amid the COVID-19 Pandemic in Indonesia. Universal Journal of Accounting and Finance, 9(4), 757 - 763. DOI: 10.13189/ujaf.2021.090421.

Copyright $\bigcirc 2021$ by authors, all rights reserved. Authors agree that this article remains permanently open access under the terms of the Creative Commons Attribution License 4.0 International License

\begin{abstract}
The spread of the coronavirus in various countries has brought many changes in various sectors, including the financing sector, many people are doing re-credit, asking for leniency in installments due to limited access, income, employment, and others due to the implementation of the lockdown. Likewise, what happened in Indonesia was that many people panicked about financing at banks and BMTs. The purpose of this research is to analyze the performance of sharia financing in sharia financing institutions and cooperatives amid the Covid-19 pandemic. The method used is field research using the qualitative paradigm with the phenomenological approach. Primary data were collected from observations and direct interviews, while secondary data were obtained through books, journals, articles related to Islamic financing. Following the data processing, analysis was carried out using data validity techniques and data reduction, thus conclusion could be drawn. The research was conducted in three sites; BMT (Baitul Mal wa Tamwil) Amanah Ummah, BMT Kube Colomadu Sejahtera, and BMT Wanita Mandiri. The results of the study showed that sharia financing activities at those BMTs decreased due to the impact of the Covid-19 pandemic. Likewise, the level of customer ability fell due to the physical distancing in some of the customer's residences, reduced income, and increased consumptive costs, which led to default in customers at three different BMT locations. The implications of this research are expected for the customer to be more cooperative in fulfilling obligations in paying installments and being more committed to fulfilling mutual agreements. For BMT managers to be more careful in choosing customers and make better efforts to resolve
\end{abstract}

customer's defaults in a family way. For the Government to be able to make policies related to customers and BMTs, so that they do not feel disadvantaged by the current pandemic conditions and can feel more secure and comfortable in any conditions.

Keywords Sharia Financing, Savings and Loan, BMT, Cooperatives, COVID-19 Pandemic

\section{Introduction}

At the beginning of 2020, the world was shocked by the coronavirus which has spread globally and Indonesia is no exception. The coronavirus brings many negative impacts on individuals, society, and also companies [1]. The community who were peaceful became anxious, panicked, and scared. This state has led to panic buying, in other words, excessive shopping. In addition, the impact this virus has made on people is that activities can only be conducted online at home. These activities include work, school, college, and even prayer at home. This virus prompts imbalance in all sectors [2].

The imbalance particularly affects the economic sector. The government attempted to counteract the impact of the COVID-19 on the Indonesian economy by fiscal stimulus. The government has taken steps through a budget re-focusing for the health and social assistance sectors. Furthermore, the government issued phase II of fiscal stimulus to maintain public purchasing power and the sustainability of the business sector for 6 months began 
from April to September 2020. This policy was done to support maintain business liquidity [3].

Another effort is that the government issued a non-fiscal stimulus to encourage export-import activities, such as accelerating the export-import process for reputable traders as well as increasing, accelerating export-import services and supervision through the National Logistic Ecosystem (NLE) to improve national logistics efficiency and simplifying and reducing the number of Bans and Restrictions on raw materials export and import. In the financial sector, the Government issued a stimulus as a counter-cyclical policy, such as restructuring MSMEs' loans with a fluent quality, banks that provide stimulus to debtors based on repayment schedule, and restructuring all loans regardless of the credit ceiling [4].

Covid-19 caused an economic shock, which affected the economy of individuals, households, companies at the micro, small, medium, and large levels, and even affected the country's economy at the local, national, and global levels. The significant impact of Covid-19 on world economic development is also a challenge for the business sector, including the banking financial services. According to Sharia banking statistics as of January 2020, the number of Sharia Commercial Bank office networks has reached 1,922 branches across various regions in Indonesia which are mostly found in Java Island, which is in line with the most Covid-19 cases (Sharia Banking Statistics, January 2020). It shows that most of the Sharia Bank Offices are in the red zone [5].

The implementation of PSBB (large-scale social restrictions) has influenced financial institutions which led to the jammed business sector. The problem arising is that debtors face difficulties in repayment, however, if left unchecked, it will cause problems with the bad credit score. Meanwhile, bank soundness level is very much influenced by bad credit scores. A state in which banks experience problems in the credit implementation, which in credit distribution facing problems of the debtor's inability to pay according to the schedule including; principal and interest which cause loans to be classified as non-performing loans [6].

The impact of covid-19 has also been experienced by microfinance institutions such as baitul mal wa tamwil. For instance, the application for Islamic financing has decreased, and it simultaneously affected the ability of customers to pay installments at baitul mal wa tamwil. Baitul mal wa tamwil is a financial institution with a sharia concept established as an option that combines the concept of mal and tamwil in an institutional activity. One of the main tasks of Islamic financial institutions is channeling funds included in financing. Distribution of funds is collected from parties with excess funds to parties who are lack of funds. Financing activities are funds transferred to finance economic/business activities that generate added value through the process of production, trade, or service delivery. One way for business actors to meet their capital needs is to seek financing from financial institutions or Islamic banking [7].

The distribution of baitul mal wa tamwil funds is a transaction to provide funds to its members or prospective members who are not against sharia principles nor do they violate positive law. The function of channeling funds is to increase the efficiency, circulation, and flow of capital of members or prospective members of BMT, to increase BMT investment activities, and is the largest source of BMT income. Distribution as a productive activity in baitul mal wa tamwil during pandemic did not run compared to before pandemic. The pandemic has disrupted a lot of fundraising activities in Baitul Mal Wa Tamwil. As in the case, customers were unable to pay their obligations during the pandemic. Their payments were disrupted due to a specific factor, which is PSBB in every region. Another problem also emerged from PSBB, such as customers work to fulfill their obligations to repay funds which ultimately affected the BMT's performance related to sharia financing amid the pandemic [8].

Based on the description, this research describes and examines problems related to sharia financing for customers and related financial institutions that have been affected by the pandemic and is elaborated in more comprehensive field research. Thus, the problem formulation will be presented [9].

First, does the covid-19 pandemic affect customer financing application at three BMTs? Second, how is the customers' ability at three BMTs to fulfill their obligations to Islamic financing during a pandemic? Third, how do three BMTs resolve the defaults of their customers during the pandemic?

\section{Materials and Methods}

This research is based on field research, a descriptive qualitative, which is research procedures that generate descriptive data in the form of written or spoken from qualified participants who are observable [10]. The research utilized a phenomenological approach. The research technique used data observation according to the problem formulation, interviews, and documentation.[11]

Data collection employed data reduction and was then concluded using a narrative. The object of this research is BMT which consists of three BMTs; BMT Amanah Ummah, BMT Kube Colomadu Sejahtera, and BMT Wanita Mandiri.

Meanwhile, the research subject is the analysis of the sharia financing performance in sharia savings and loan cooperatives in Surakarta during the Covid-19 pandemic and managers in those three BMTs. 


\section{Result and Discussion}

\subsection{The Economic Impact of The People Amid the Pandemic}

The Indonesian economy is inseparable from the impact of Covid-19. The various negative impacts in a wake of Covid-19 reduced the performance of the world economy in 2020. Bank Indonesia predicted that the world economic growth in 2020 was $2.5 \%$ YoY, decreasing compared to 2019 growth of $2.9 \%$ YoY. The world economy is predicted to show better growth in 2021 by $3.7 \%$, following the Covid-19 countermeasure prediction [12]. Hence, Bank Indonesia has revised the outlook for Indonesia's economic growth in 2020 and 2021 to 4.2\% $4.6 \%$ YoY and 5.2-5.6\%, respectively. The prospect of global economic growth and Indonesia 2020 would be lower once the Covid-19 outbreak continues to spread, triggering the implementation of stricter restrictions or social distancing policies in various countries, and global financial market pressures continue due to high uncertainty [13].

The future economic prospects will be influenced by the efforts of various countries to overcome the Covid-19. At least, policy responses can be directed to mitigate risks in four aspects; people, companies, economy, and financial system. In terms of the human aspect, strategies that could be considered include bolstering health-care resources and providing economic support to affected areas. In the corporate aspect, policies need to be directed at reducing financial pressures experienced by companies, such as by reducing or deferring tax payments from those affected economic sectors and increasing the availability of liquidity and credit to affected companies. Regarding the economy and financial system, policies need to be aimed at maintaining stability by providing liquidity to banks, adopting optimal monetary policies in response to financial market pressures, and implementing policies to encourage public investment [14].

In this pandemic situation, according to the Ministry of Cooperatives and Small and Medium Enterprises, it was reported that 37,000 MSMEs were seriously affected by the pandemic shown by: approximately 56 percent reported a decrease in sales, 22 percent faced problems in financing aspect, 15 percent informed problems in the distribution of goods, and 4 percent reported difficulties in obtaining raw materials. Those problems are also significantly widespread if connected to the large-scale social restrictions (PSBB) policy which is implemented in several regions in Indonesia [15].

Financing is funding provided by a party to another party to support predetermined investments, either by an individual or by an institution. Meanwhile, Law no. 10 of 1998 on banking states that financing is the provision of funds or equivalent claims upon an agreement between the Bank and the other party which requires the financed party to return funds or claims after a certain period in exchange for profit sharing [16].

Article 1 number (12): Financing based on sharia principles is the provision of money or equivalent claims upon an agreement between the Bank and the other party which requires the financed party to return funds or claims after a certain period in exchange for profit sharing. Number (13): Sharia principles are rules of an agreement according to the Islamic law between a bank and the other party to deposit funds or to finance business activities, or other activities following sharia, including financing based on the principle of profit-sharing (mudharabah), financing based on equity participation (musyarakah), sale and purchase of goods for profit (murabaha), or the financing of capital goods based on the principle of the pure lease without choice (ijarah), or with the option of transfer of ownership of leased property from the bank to another bank ( ijarah wa iqtina) [17].

This product is the duty of baitul mal wa tamwil is part of the management function of baitul mal wa tamwil. This product demands the managers of baitul mal wa tamwil to possess good funding capabilities and strategies. In collection management, the main principle is to generate trust from the public in BMT and other aspects that are closely related to performance. BMT as a joint venture institution requires the management of member funds to be committed and have the integrity to muamalah principle. The process of fundraising must consider two items; the principles of sound and correct funds, and procedures for approval, documentation, administration, and supervision of fundraising. The source of fundraising must regard its halal reference and avoid collecting funds that against sharia and contradict government regulations [18].

Baitul maal wa tamwil raises a limited amount of funds. The ability to identify various sources of funds and present them to various products of sale value is essential. These fundraising products practice wadiah, mudharabah mutlaqah or mudharabah muqayyadah contracts, and social contracts in the form of zakat, infaq, alms, cash waqf, and grants [19].

The distribution of funds by baitul mal wa tamwil is a transaction to provide funds to its members or prospective members who are not against sharia principles nor do they violate positive law [16]. The function of channeling funds itself is to increase the efficiency, circulation, and capital flow of members or prospective members of BMT, to increase BMT investment activities, and is the largest source of BMT income. The distribution of these funds can be divided upon their purpose of use and the type of financing, comprising: working capital financing, investment financing, and multipurpose financing. Meanwhile, BMT financing is divided into two: small business financing and consumption financing.

\subsection{Financing Default}

Default derives from the Dutch term which means poor 
performance. According to Wirjono Prodjodikoro, default is the absence of achievement in the law of the agreement, a task that must be carried out as the content of an agreement. According to Subekti, default is negligence which can be formed in four types: not doing what is promised will be done; carry out what was promised but not as agreed on the agreement; doing what was promised but it was too late; Doing something according to the agreement shall not be done. Legal instruments and laws and regulations that force the operations of LKS (Social Welfare Institutions) in Indonesia support the strengthening of the relationship pattern between LKS and customers based on the will to enforce the sharia system [10].

Thus, every contract made by the parties must be carried out voluntarily and in good faith. A contract is referred to as the akad or agreement given by one party to the other party which entails consequences. In the practice of sharia financing in sharia financial institutions, financing a customer is deemed default if he does not fulfill the obligations or is late in carrying out agreement according to the agreement at the time the contract came into effect. Negligence or default is pre-stated officially in a statement of negligence, using notification (subpoena) to the alleged party to carry out its obligations. In a financing contract based on default, it can be immediately fulfilled without notification or statement of negligence from the bank, considering that the default condition has been evident with the past due which violates the initial agreement [20].

Sharia financial dispute resolution has two broad lines; litigation and non-litigation. Non-litigation settlement is resolving disputes outside the court that are usually taken by sharia financial institutions and customers to settle problems such as rescheduling, reconditioning, restricting, and execution of collateral through the state auction services. However, many settlement cases have taken litigation, which is pursuing before the court that has competence, both absolute competence, and relative competence [21].

\subsection{Customer Application for Financing in Three Baitul Mal Wa Tamwil Amid the COVID-19 Pandemic}

The covid-19 pandemic in Indonesia affected various aspects. It has affected the economy, in which the Islamic financial institutions Baitul Mal Wa Tamwil exist. The impact in baitul mal wa tamwil can be observed from the application for sharia financing. Its members or customers showed a declining trend in submitting fund applications. Although three BMTs had different conclusions, two out of three BMTs had the same impact - the application for customer financing until this November was affected, whereas one BMT was only disturbed at the beginning of the pandemic, from March to May. Reasons for such condition on the application for financing were due to the physical distancing in villages applied in several customer residences, the stipulation of presidential policy where customer installments were loosened, also members who were more restrained as a result of the consumptive pandemic conditions that emphasized self-restraint from opening business opportunities, and more. Finally, Islamic financial institutions such as BMT also limited application for financing [21].

Based on the results of interviews conducted with managers at three BMTs, the application for financing during the pandemic experienced the repercussions of the Covid-19 pandemic. The activity of Islamic financing application in three BMTs decreased as a result of customers who chose to refrain from consumptive attitudes during the pandemic as an effort to bring food to the table and businesses that plunged so the risk was high for them to opt to apply for financing. BMT also limited financing application as prudence in providing funds to customers in such circumstances that do not favor the economy. Hence, restrictions on financing applications were conducted by sorting out customers that were less affected from Covid-19 [5].

\subsection{Customer's Ability to Fulfill Their Obligations by the Sharia Financing Agreement amid the COVID-19 Pandemic}

The ability of customers in three BMTs to fulfill their financing obligations during a pandemic showed an equal result; the inability of customers to fulfill their obligations during the pandemic. The powerless state of customers to fulfill obligations in installments was promoted by many inoperative businesses, unemployment, and soaring needs. Problematic financing is the customer's state in which he is unable to pay his obligations or the result of the customer's default installments.

The conclusion of the customer's ability during this pandemic falls into a category of special attention where the installment due date does not reach 90 days. The decline in the customers' ability in three BMTs happened due to erratic employment factors, unhealthy businesses condition, and increased consumptive costs. Hence, the decline in the customer's ability has affected BMT financing and then limited financing activities. This ability is categorized at level two, a state where the customer's experiences financial problems during a pandemic which results in the customer's being unable to pay their obligations. The time criterion is before up to 90 days because the customer's ability is calculated to decrease at the beginning of the pandemic, namely March to May. In the first three months, the customers' ability to pay their obligations decreased, yet the BMT policy is by the restructuring of the rescheduling method for customers whose abilities had decreased [6]. 


\subsection{Default Settlement of Customer at Baitul Mal Wa Tamwil amid the COVID-19 Pandemic}

Cases in the civil sector, such as muamalah, have various kinds of dispute resolution. Disputes in business or muamalah have been regulated in the Civil Code in arbitration and alternative dispute resolution of Law Number 30 of 1999. The method used in the Bank Indonesia regulation is that dispute resolution is carried out in three types; rescheduling, reconditioning, and restructuring. As stated by Faisal from BMT Amanah Ummah below:

"At the beginning of the pandemic, we conducted a restructuring, looked for data on members who were affected, then notified them to submit a restructuring to BMT. In the first three months of the pandemic period, efforts were made for those affected members to be able to pay a margin, and the remaining principal was divided by the remaining time. Therefore, the affected members were rescheduled. After three months, the members could pay their obligations which have been divided evenly from the remaining balance. If it has passed due, the BMT will extend the due date from two months to three months”.

The results of the interviews from the three BMTs above show that the default settlement in efforts was carried out through various processes. The effort taken was a persuasive approach, in which the BMT meets and asks about the customers' problems who cause problematic financing - bad credit. A good response will stimulate customer efforts to pay according to their ability, then according to the margin. The settlement with a notification letter will not occur and even at the time, the bill is confiscated. The practice of default settlements at three BMTs during this pandemic employed the same mechanism. There is a settlement with a persuasive approach, payment according to ability, payment according to margin, and rescheduling.

Table 1. The Results of the Interviews from the Three BMTs

\begin{tabular}{|c|c|c|c|}
\hline $\begin{array}{c}\text { BMT } \\
\text { Institution }\end{array}$ & Rescheduling & $\begin{array}{c}\text { Default } \\
\text { Settlement/ } \\
\text { Reconditioning }\end{array}$ & Restructuring \\
\hline $\begin{array}{l}\text { Amanah } \\
\text { Ummah } \\
\text { Kube }\end{array}$ & & - & - \\
\hline $\begin{array}{l}\text { Colomadu } \\
\text { Sejahtera }\end{array}$ & & - & - \\
\hline $\begin{array}{l}\text { Wanita } \\
\text { Mandiri }\end{array}$ & & - & - \\
\hline
\end{tabular}

Some of the solutions for the three BMTs applied a non-litigation approach, where three BMTs opted for a rescheduling mechanism. The solution in the event of a breach of contract agreement will be settled through peaceful settlement. Avoiding default trials by customers before the court during the pandemic has been resolved employing peace. Similar to the concept of Islamic law in resolving sharia economic disputes, there are three types, encompassing al-Sulh, tahkim, and wilayat al-qadha.[22]

In practice, the initial dispute settlement was done with a persuasive approach. Following this careful effort, it is expected that customers who are unable to fulfill their obligations will be able to provide suggestions or solutions to pay installments. Thus, rescheduling exists as an effort to resolve with a form of mediation that is included in the non-litigation category. Mediation is carried out as a reconciliation effort between the customer and BMT which does not involve a third party as an intermediary to resolve the default problem. In Islam peace (Sulh) is the best approach to solve Islamic economic problems [23].

This method is done as a form of a peace agreement between the customer and the BMT through rescheduling. All things considered, the default settlement carried out by BMT amid the pandemic is following Islamic law, through the method of such (peace) or, in positive law, non-litigation methods, using mediation.

Sulh method is used as a good solution between two parties to find a good solution [24]. for instance, rescheduling practiced by BMT in resolving problematic financing. BMT as the owner of the funds provides leeway for time and the number of installments according to the remaining obligations of the customer as the recipient of the funds. This settlement will not end in court trial if the customer responds properly to the solution provided by the BMT [25]. so that non-litigation employing mediation is carried out on customer default settlement. The presence of the first party provides the option to allow more time to fulfill obligations and the number of installments according to the remaining obligations of the customer.

\section{Conclusions}

The conclusions of this study are: Application for Islamic financing in three BMTs decreased due to the physical distancing in several villages where the customer resides, causing limited movement of all activities, unstable employment where the customers earn a low income, the increasing need for life due to a full day of activities at home, and businesses that are not running as usual, and low-profit level earned during the pandemic. As a result of the reduction, BMT also limited the existing Islamic financing on the products offered. The decrease in demand for financing applications also affected the fund collection since people use their funds for daily needs to survive during the Covid-19 pandemic. The customer's ability to fulfill their obligations according to the initial agreement during the Covid-19 pandemic decreased. The decline in customer ability was caused by the same factor that caused the decline in demand for financing applications at BMTs: unstable employment, high consumptive needs, and businesses experiencing a drop in 
profits due to poor economic activity during the Covid-19 pandemic.

As a result of the decreased customers' ability to pay installments, it resulted in default. This state in three BMTs were resolved through the rescheduling method.

Suggestions for customers are to be more cooperative in fulfilling obligations in paying installments and to be more committed to fulfilling mutual agreements. Meanwhile for BMT managers to be more careful in sorting out customers and strive well in resolving customer's defaults in peace, such as continuing to implement discussion to reach consensus and maintain good relations with customers and creating regular monitoring after rescheduling to observe customer business developments. The government is to be able to make policies so that customers and baitul mal wa tamwil are not disadvantaged by the current pandemic conditions. This policy can also help baitul mal wa tamwil and its customers feel more secure and comfortable in any situation.

\section{Acknowledgments}

The authors would like to thank the rector UMS (Universitas Muhammadiyah Surakarta) and the chairman and staff of the LPPI (Lembaga Pengembangan Publikasi Ilmiah) UMS for supporting the publication of this article.

\section{REFERENCES}

[1] E. N. Aisyah, Z. Zuraidah, and R. R. Maulayati, "Risk Mitigation of Covid-19 Pandemic in Baitul Maal Wat Tamwil ," Proc. Int. Conf. Eng. Technol. Soc. Sci. (ICONETOS 2020), vol. 529, no. Iconetos 2020, pp. 691696, 2021, doi: 10.2991/assehr.k.210421.100.

[2] R. N. Ichsan, S. Suparmin, M. Yusuf, R. Ismal, and S. Sitompul, "Determinant of Sharia Bank's Financial Performance during the Covid-19 Pandemic,” Budapest Int. Res. Critics Inst. Humanit. Soc. Sci., vol. 4, no. 1, pp. 298 309, 2021, doi: 10.33258/birci.v4i1.1594.

[3] H. S. Disemadi and A. I. Shaleh, "Banking credit restructuring policy amid COVID-19 pandemic in Indonesia,” J. Inov. Ekon., vol. 5, no. 02, pp. 63-70, 2020, doi: 10.22219/jiko.v5i3.11790.

[4] A. R. Azhari and R. Wahyudi, "Analisis Kinerja Perbankan Syariah Di Indonesia: Studi Masa Pandemi Covid-19," Ekon. Syariah Indones., vol. X, no. 2, pp. 67-83, 2020.

[5] A. Abbas and A. A. Frihatni, "The Social Role of Islamic Banks in Indonesia during the Pandemic of COVID-19: Reflection of Market Share,” Eur. J. Islam. Finance., vol. 16, no. January, pp. 1-8, 2020, doi: $10.13135 / 2421-2172 / 4914$.

[6] S. Sutrisno, B. Panuntun, and F. I. Adristi, “The Effect of Covid-19 Pandemic on the Performance of Islamic Bank in
Indonesia,” Equity, vol. 23, no. 2, p. 125, 2020, doi: 10.34209/equ.v23i2.2245.

[7] A. Z. D. Trimulato, "RESTORATION FOR REAL SECTOR OF SMES WITH SUKUK INSTRUMENTS DURING COVID-19 PANDEMIC,” 2020.

[8] M. Nugroho, "Urgensi Penerapan Islamic Corporate Governance Di Baitul Maal Wat Tamwil (BMT)," Kaji. Bisnis STIE Widya Wiwaha, vol. 23, pp. 64-70, Mar. 2017, doi: 10.32477/jkb.v23i1.204.

[9] A. Ayange, N. C. Emmanuel, I. H. Rosemary, U. C. Ndudi, and U. E. Samuel, "Effect of capital structure on firms performance in Nigeria," Universal Journal of Accounting and Finance, vol. 9, no. 1, pp. 15-23, 2021, doi: 10.13189/ujaf.2021.090102.

[10] S. Shobron and A. Anshori, "Method for Developing Soft Skills Education for Students," Universal Journal of Educational Research, vol. 8, no. 7, pp. 3155-3159, 2020, doi: 10.13189/ujer.2020.080744.

[11] S. Shobron and S. A. Rahman, "Humanist islam in indonesia ahmad syafii maarif perspective," Humanit. Soc. Sci. Rev., vol. 7, no. 6, pp. 780-786, 2019.

[12] A. Alam, R. S. Nizam, and M. T. Hidayat, "The Role of Islamic Microfinance Institution in Empowering Indonesian Fishing Communities," Universal Journal of Accounting and Finance, vol. 9, no. 2, pp. 178-183, 2021, doi: 10.13189/ujaf.2021.090205.

[13] M. Iman and S. Mihajat, “Oman’s Islamic Banking Performance amidst Covid-19 Outbreak: Prospects and Challenges,” Shirkah J. Econ. Bus., vol. 6, no. 1, pp. 38-51, 2021.

[14] S. Rahmatika and M. N. Kholid, "Jurnal Ekononomi \& Keuangan Islam,” J. Ekon. Keuang. Islam, vol. 7, no. 2, pp. 92-104, 2020.

[15] C. Susilawati, "Role of The Halal Industry in Recovering the National Economy in Covid-19 Pandemic," Int. J. Nusant. Islam, vol. 8, no. 2, pp. 202-214, 2020, doi: 10.15575/ijni.v8i2.10807.

[16] P. Putri, "Social Level Parameters of Banjar Society in the Tradition of Jujuran Islamic Law Perspective,” vol. 529, no. Iconetos 2020, pp. 87-90, 2021.

[17] Muthoifin, "SHARIA AND HUMAN RIGHT: Parse Conflict in Indonesia Towards Peace Sharia Perspective," Conf. Int.

[18] B. P. Muthoifin, "Readiness Towards Halal Tourism in Indonesia Perspective of Reality and Religion,” Int. J. Adv. Sci. Technol., vol. 29, no. 8, pp. 862-870, 2020.

[19] M. M. Nugroho, "Outsourcing System in View of Islamic Law : Study on Employees at Universitas Muhammadiyah Surakarta,” vol. 529, no. Iconetos 2020, pp. 91-95, 2021.

[20] K. Kambara, "Economics of Ar-Rahnu (Islamic Pawnbroking): Issues and Cases in Brunei Darussalam," Jab. Kemajuan Islam Malaysia, vol. Edisi Khas, no. March, pp. 87-96, 2017.

[21] Muthoifin, "BEREKONOMI DAN INVESTASI DALAM BINGKAI SYARIAH (Studi terhadap Esai "Emasku Pencerah Mimpiku'),” 5TH URECOL PROCEEDING 18 
Febr. 2017 UAD, Yogyakarta, no. February, pp. 1179-1185, 2017.

[22] M. Nuha, Sudarno Shobron, "Education and Leadership in Indonesia: A Trilogy Concept in Islamic Perspective," Universal Journal of Educational Research, vol. 8, no. 9, pp. 4282-4286, 2020, doi: 10.13189/ujer.2020.080954.

[23] Muthoifin, "Shariah Hotel and Mission Religion in Surakarta Indonesia,” Humanit. Soc. Sci. Rev., vol. 7, no. 4, pp. 973-979, 2019, doi: 10.18510/hssr.2019.74133.

[24] E. Studies and S. Asia, "NEW TRENDS IN SOUTHEAST ASIA HOTEL SHARIAH :"

[25] M. Surahman and P. Adam, "Penarapan Prinsip Syariah Pada Akad Rahn Di Lembaga Pegadaian Syariah," Law Justice, vol. 2, no. 2, pp. 135-146, 2018, doi: 10.23917/laj.v2i2.3838. 